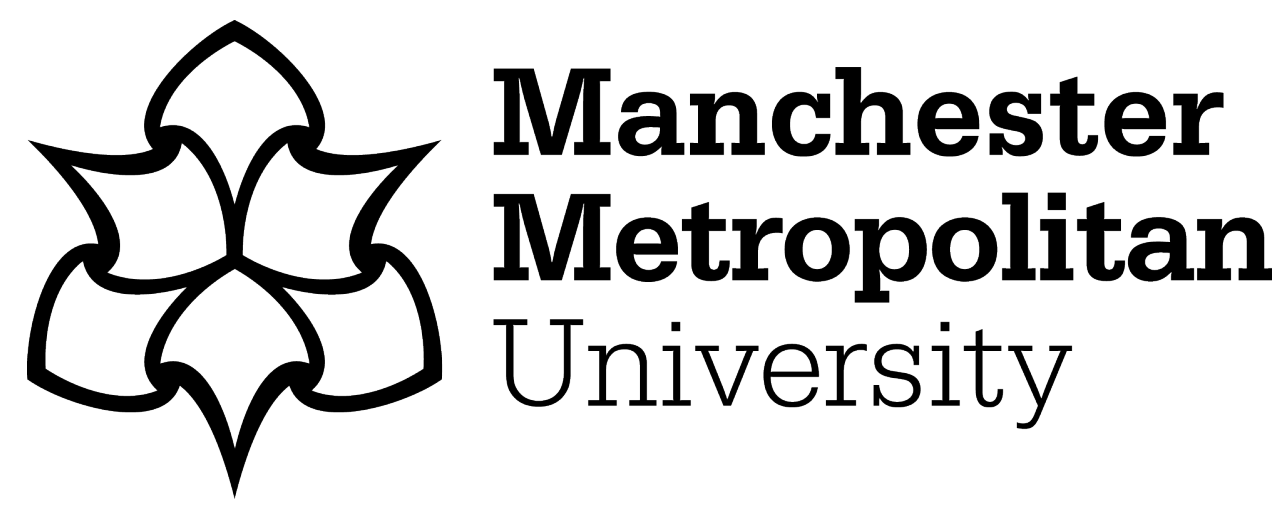

Lindfield, Peter ORCID logoORCID: https://orcid.org/0000-0001-8393-9344 (2020) Gothic Revival Architecture Before Horace Walpole's Strawberry Hill. In: The Cambridge History of the Gothic : Volume 1: The Long Eighteenth Century. Cambridge University Press, pp. 97-119. ISBN 9781108472708

Downloaded from: https://e-space.mmu.ac.uk/626285/

Version: Accepted Version

Publisher: Cambridge University Press

DOI: https://doi.org/10.1017/9781108561044.005

Please cite the published version 


\title{
Gothic Revival Architecture Before Horace Walpole's Strawberry Hill
}

\author{
PETER N. L I N D FIE L D
}

Strawberry Hill, the Gothic villa of Horace Walpole (I7I7-97), was constructed within sight of the River Thames in Twickenham in the mid-tolate eighteenth century, and stands today as one of the most important landmarks of eighteenth-century British architecture and design. ${ }^{\mathrm{I}}$ We know more about the building and its contents than about almost any other structure that was realised in the Gothic mode in the mid-Georgian period. Walpole wrote extensively about the house and its construction to friends, correspondents and designers; numerous executed and rejected designs survive for Strawberry Hill's exterior, interior and furniture; and the house's art collection, as well as attributions and sources for the house's various parts, from ceilings to chimneypieces, are documented in an official 'catalogue', 'description', or 'guide' that Walpole wrote and had printed at his private press: A Description of the Villa of Mr. Horace Walpole (I774, I784). ${ }^{2}$ In I842, Strawberry Hill's contents were put up for auction by George Robins in a spectacular 24-day sale; the sale catalogue is another monument to Walpole's collection and his villa, even if Robins's auction effectively dismantled Strawberry Hill and dispersed the collections that Walpole had amassed largely at and for his house. ${ }^{3}$ Thereafter, Strawberry Hill was transformed into a bare skeleton, stripped of its historicising, antiquarian and contemporary collection of objects and paraphernalia. But not all was lost: shortly after his graduation from Yale University in I9I8, the redoubtable twentiethcentury American scholar Wilmarth Sheldon Lewis energetically began to

I See Michael Snodin, with Cynthia Roman (eds), Horace Walpole's Strawberry Hill (New Haven and London: Yale University Press, 2009) and Clive Wainwright, The Romantic Interior: The British Collector at Home, 1750-1850 (New Haven and London: Yale University Press, 1989), pp. 7I-I06.

2 See Stephen Clarke, The Strawberry Hill Press \& Its Printing House: An Account and an Iconography (New Haven and London: Yale University Press, 20II), pp. 26-7.

3 George Robins and Dudley Costello, A Catalogue of the Classic Contents of Strawberry Hill Collected by Horace Walpole (London, I842). 
buy, collect and amass all manner of Walpoliana at his home at Farmington in rural Connecticut, eventually going on to edit the capacious 48-volume The Yale Edition of Horace Walpole's Correspondence (1937-83), and indefatigably promoting for the rest of his life Walpole as a rich topic for study. For all of these reasons, together with the fact that Lewis helpfully sought out and brought together so much of Walpole's Library and objects from the villa, especially furniture, Strawberry Hill has been reconstructed, even if the house and the objects in the Lewis Walpole collection are separated from one another by the Atlantic. Strawberry Hill has consequently been elevated, especially during the twentieth century, from what was strictly a modest, if idiosyncratic, eighteenth-century Gothic villa to the pre-eminent example of mid-Georgian Gothic Revival architecture. ${ }^{4}$ Walpole's status as a prolific eighteenth-century correspondent, historian, writer on art and architecture, and the son of Britain's first Prime Minister, as well as Lewis's collection of Walpoliana, helped substantiate the villa's pre-eminence.

Michael McCarthy's landmark publication on the Gothic Revival in eighteenth-century Britain, The Origins of the Gothic Revival (1987), is based heavily upon Lewis's Walpoliana, and the monograph reproduces the bulk of the Strawberry Hill-related manuscript designs and correspondence in the collection. As his book's title suggests, McCarthy seeks to address the beginnings of the Gothic Revival in Britain. He opens by claiming that 'this book is born of the conviction that the beginnings of the gothic revival in architecture have hitherto been presented to the public in an incomplete and therefore mistaken manner. ${ }^{5}$ McCarthy continues by assessing Walpole's place in the reawakened interest in the medieval or 'Gothic' past in the eighteenth century by arguing that the mastermind behind Strawberry Hill, with good reason, 'played such a large part in the revival that he cast himself in the role of its originator'. 6 The emphasis that McCarthy places upon the Gothic milieu around Walpole perpetuates the notion of Strawberry Hill as the pioneering work in the style, and Walpole as Gothic's standard-bearer. This assessment corresponds with the first historical study of the Gothic Revival, Charles Locke Eastlake's History of the Gothic Revival (1872), which introduced eighteenth-century Gothic design by framing Strawberry Hill as the foremost building emerging from a period 'more distinguished than

4 See Wilmarth Sheldon Lewis, Collector's Progress (New York: Knopf, 195I).

5 Michael McCarthy, The Origins of the Gothic Revival (New Haven and London: Yale University Press, 1987), p. I.

6 McCarthy, The Origins of the Gothic Revival, p. I. 
another for its neglect of Gothic'. ' Kenneth Clark's The Gothic Revival: An Essay in the History of Taste (1928), the first twentieth-century work to approach the Gothic Revival with any level of seriousness, similarly places Walpole and his villa at the heart - although not the forefront of the architectural mode, in particular the Rococo Gothic, and, perhaps because of this, Clark believed that Walpole's villa 'has been studied at least as much as it deserves'. 8 The touring exhibition curated by Michael Snodin, Horace Walpole's Strawberry Hill, at the Yale Center for British Art, New Haven, Connecticut, and the Victoria and Albert Museum, London (2009-IO), together with the exploration of Walpole's sexuality and its theorised impact upon his aesthetic choices, have enshrined the centrality of Walpole and Strawberry Hill to any understanding of the Gothic Revival in Georgian Britain. ${ }^{9}$ Marion Harney's Place-Making for the Imagination (2013) continues to assert the importance of the villa and Walpole to eighteenth-century British aesthetics, and helpfully brings together a large proportion of Walpole's writings about the house and its garden. ${ }^{\text {Io }}$

While it is impossible to deny the importance of Walpole and Strawberry Hill to eighteenth-century Gothic design, Walpole's villa is far from being the first or, indeed, the most significant example of Gothic Revival design from the period. This is especially the case if one considers the important distinction between two very different types of post-medieval/Tudor Gothic: Gothic Survival and Gothic Revival. Sir Howard Colvin articulated cogently the difference between these two kinds of Gothic in his landmark I948 essay, 'Gothic Survival and Gothick Revival', most recently republished in 1999. ${ }^{\text {II }}$ Referring to the lingering tradition of Gothic in post-medieval English building, Colvin writes that the style:

7 Charles Locke Eastlake, A History of the Gothic Revival pp. 42, 43-9.

8 Kenneth Clark, The Gothic Revival: An Essay in the History of Taste, 2nd edition (London: Murray, 1962), pp. 46, 57-62.

9 Snodin, with Cynthia Roman (eds), Horace Walpole's Strawberry Hill; George E. Haggerty, Men in Love: Masculinity and Sexuality in the Eighteenth Century (New York: Columbia University Press, 1999), pp. 152-57; Haggerty, 'Queering Horace Walpole', Studies in English Literature 1500-1900 46:3 (2006): 543-6I; and Matthew M. Reeve, 'Gothic architecture, sexuality and license at Horace Walpole's Strawberry Hill', Art Bulletin 95:3 (September 20I3): 4II-39.

Io Marion Harney, Place-Making for the Imagination: Horace Walpole and Strawberry Hill (Farnham: Ashgate, 2013), pp. I-28, I29-218.

II Howard Colvin, 'Gothic Survival and Gothick Revival', in Howard Colvin, Essays in English Architectural History (New Haven and London: Yale University Press, 1999), pp. 2I7-44. 
is essentially a mason's architecture (what carpenter's Gothic could be like Batty Langley was soon to demonstrate), and its survival was bound up with the survival of the mason as an independent craftsman. In eighteenthcentury London the mason was losing ground as a designer to the new profession of the architect, and as a builder to the expanding trade of bricklayers, neither of which understood Gothic traditions. And so Gothic retreated with the masons to the stone districts of the Midlands, the West and the North. ${ }^{\text {I2 }}$

The exact genesis of the Gothic Revival is, consequently, difficult to pinpoint with any precision given that the style had not entirely fallen out of practice since the medieval period. Local builders and masons who worked in historical ways and styles well into the seventeenth century and beyond were practitioners of 'traditional' medieval Gothic too.

When, then, was the Gothic revived? This is a challenging question, and Colvin, for one, shows that the Gothic style was very much alive in the seventeenth century and even in the early Georgian period, an age that adopted and followed, almost universally, Classical architecture's forms and motifs. ${ }^{\mathrm{I}} \mathrm{He}$ writes that there were 'parts of the country where the tradition of Gothic masoncraft had survived both the Reformation and Civil War and was alive in the early eighteenth century'. ${ }^{\mathrm{I}}$ This tradition, however, is very different from what we think of today as Gothic Revival architecture and design, which is markedly different in form, appearance, construction and syntax from the conservatively and traditionally practiced 'Gothic Survival'. The Gothic Revival can be separated quite easily in formal and visual terms simply by considering the practitioner's background: an insular, historically trained mason (Survival), or a 'professional' architect lacking any understanding of the style (Revival) who bases his work - perhaps just superficially imitative - upon what was often only a limited understanding or comprehension of medieval architectural forms and motifs.

The Gothic Revival, then, was spearheaded not by builders who continued to work in traditional ways but by a new generation and distinct group of professional architects who were not schooled in, and who had little understanding of, medieval buildings, including their form, ornament and constructional logic. This gap in knowledge and lack of expertise meant that these Gothic architects, when called upon, created Gothic structures - either

I2 Colvin, 'Gothic Survival', p. 223.

I3 See, for example, Giles Worsley, Classical Architecture in Britain: The Heroic Age (New Haven and London: Yale University Press, 1995), pp. I-I74, I97-288.

I4 Colvin, 'Gothic Survival', p. 218. 
real or imaginary, as in the case of book illustrations - that, at best, only attempted to mirror, recreate, hint at or reference some aspect or aspects of the medieval style. Their works, consequently, were systematically different from the output of medieval masons and those keeping centuries-old building techniques and stylistic formalities alive and in place outside of the metropolis. ${ }^{15}$ This definition of the Gothic Revival ably describes Strawberry Hill, even though its appearance moved swiftly away from the overtly whimsical to a far more sober 'antiquarian' design as the process of construction unfolded. It also characterises other examples of Georgian Gothic architecture and design that predate even the earliest work at Strawberry Hill by at least half a century; there is a rich and important genealogy of Gothic Revival - as opposed to Gothic Survival - design before Strawberry Hill in Britain that is easily and repeatedly overlooked when considering Georgian and Victorian Gothic as a whole. Walpole’s villa was not the fountainhead of the Gothic Revival and representing it as such is to misunderstand the style's history.

\section{Aesthetic Schism: The beginnings of the Gothic Revival}

During the seventeenth and eighteenth centuries, high-profile professional and amateur architects, including Sir Christopher Wren (I632-I723), Nicholas Hawksmoor (c. I662-I736), Sir John Vanbrugh (I664-I726), William Kent (c. I686-I748) and Batty Langley (I696-I75I), followed the mainstream aesthetic of Classicism. Others, such as Sanderson Miller (I716-80), worked largely in the medieval-inspired style, but Miller was the exception rather than the rule. Not one of these Classical architect-designers could avoid the Gothic. Some, such as Vanbrugh, embraced it actively; Langley published a highly influential Gothic pattern-book, while Kent's limited foray into pointed-arch architecture had a significant impact upon eighteenth-century Gothic buildings, interior plasterwork and furniture. Irrespective of their limited or more protracted engagement with the Gothic, these six 'Classicists', along with traditionally skilled craftsmen who were more insulated from leading London fashions, helped preserve an unbroken tradition of Gothic design that ran from the medieval period through to the eighteenth century. Their use of Gothic forms, however, fundamentally reformed the style's visual identity away from its medieval origins to create a new, distinctively modern

I5 Colvin, 'Gothic Survival', pp. 2I7-I8. 
Gothic idiom that largely followed the seventeenth- and eighteenth-century fashion for Classical, Palladian simplicity. The discussion below considers select works and designs by each architect, from Wren to Langley, illustrating the vibrant and sustained tradition of Gothic design before Walpole leased 'Chopp'd-Straw-Hall' in 1747 , the unassuming tenement that, after he purchased it in 1748 , was transformed and enlarged to become Strawberry Hill over the next three decades.

\section{Sir Christopher Wren}

Wren is known primarily for his Classical structures, including The Sheldonian Theatre, Oxford (1664-69); The New Library at Trinity College, Cambridge (1676-84); and his most prominent work, St Paul's Cathedral, London (I674-I7IO). The precise mathematical qualities and underlying simplicity of Classical architecture clearly appealed to Wren, who was a scientist and mathematician by training and eventually appointed Professor of Astronomy at Gresham College, London, in I657. Wren's leaning towards Classicism, articulated by his most well-known structures, is also expressed in his memoires, Parentalia, compiled by his son and published posthumously in 1750. Writing about English architecture, Wren here maintained that 'almost all the Cathedrals of the Gothick Form are weak and defective in the Poise of the Vault of the Aisles'; as instances of 'unbounded Fancies', their tracery 'induced too much mincing of the Stone into open Battlements and spindling Pinnacles, and littler Carvings without Proportion of Distance', even to the extent that 'the essential Rules of good Perspective and Duration were forgot'. ${ }^{16}$ Instead, Wren preferred and cherished the mathematics of Classicism, including 'Regularity and good Proportion ... of Columns, Entablatures, \&c. ${ }^{\text {I7 }}$

Nevertheless, Wren himself made occasional recourse to medieval forms. His most significant work in the Gothic mode, a style that he referred to with at least a little contempt as 'Saracenick Architecture, ${ }^{18}$ is collegiate: he erected Tom Tower over the main entrance to Christ Church, Oxford (I68I-2). The entrance tower's construction had been abandoned just above the height of the portal; Wren only had the

I6 Christopher Wren, Parentalia; or, Memoirs of the Family of the Wrens: Viz., of Matthew, Bishop of Ely, Christopher, Dean of Windsor, Etc. But Chiefly of Sir Christopher Wren in Which Is Contained, Besides His Works, a Great Number of Original Papers and Records (London, I750), pp. 305, 307.

I7 Wren, Parentalia, p. 306. I8 Wren, Parentalia, p. 306. 
college's existing fabric, and other Gothic towers, to follow as models. Wren also inserted a door (I669) into the fifteenth-century Perpendicular Gothic Divinity School, Oxford, to align with the processional entrance to his newly built Classical Sheldonian Theatre (I664-9), the University's graduation auditorium. In each instance, Wren adopted Gothic forms so that his additions would harmonise with the pre-existing structures: for Tom Tower he 'resolved it ought to be Gothick to agree with the

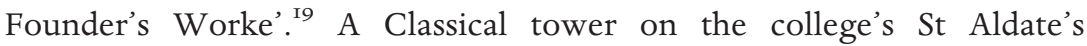
façade, like a pedimented doorway inserted into the fifteenth-century rigidly Perpendicular Gothic Divinity School, would have jarred with the existing architecture. Both of Wren's additions to these Oxford fabrics, the tower and door, are identifiably Gothic, but certain aspects of each addition do not accord with the traditions of medieval architecture exhibited by the existing structures. What are meant to be buttresses on Tom Tower, for example, are not treated with any sympathetic appreciation of medieval forms; instead, they are essentially Classical pilasters. The reticulations in the tower's two-light openings are cusped, but the cusping is too numerous and stilted in comparison with the Tudor cusped panelling below. Wren's Divinity School door is an equally distinctive re-composition of medieval forms, most noticeably the combination of a Tudor, four-centred arch with two isolated cusps placed beneath a heavily moulded ogee-flip and oversized finial. The fusion of Gothic motifs indicates Wren's assimilation of the Gothic style, but their re-composition is hardly in keeping with the rest of the structure. This was not an unthinking concession to tradition, an impulse which can be seen in the University's Schools Quadrangle and Convocation House, ${ }^{20}$ but rather for the purpose of coherence, even if this coherence is, at best, superficial.

Although only minor additions to existing structures and isolated examples within Wren's larger oeuvre, the tower and doorway demonstrate his embrace and deployment of Gothic forms as and when appropriate. Despite wanting to preserve the aesthetic unity of these buildings, his lack of understanding of, and inexperience in working with, Gothic architecture in comparison with the Classical meant that his additions were far from convincing recreations of the medieval

I9 Christopher Wren, 'Tom Tower, Christ Church, Oxford (I68I-2)', The Wren Society 5 (I928): I7-23 (p. I7).

20 John Newman, 'The Architectural Setting', in Nicholas Tyacke (ed.), The History of the University of Oxford, Vol. 4 (Oxford: Clarendon, 1997), pp. I35-78 (p. 169). 
style: though they were meant to 'agree with the Founder's Worke', they do not do so in very strict or accurate terms. ${ }^{2 \mathrm{I}}$ This is at least partially understandable given that, unlike Classical architecture, there was no nucleus of professional architects working exclusively in the Gothic style, or, indeed, treatises published on its forms, ornament or proportions in the late seventeenth century. Consequently, and save the buildings themselves, Wren had very little to go on when designing these Gothic additions. Walpole, writing about Tom Tower, observes and records Wren's failure to grasp completely and execute convincingly these medieval forms, differentiating as he does so between actual and revived instances of the Gothic style: 'the great Campanile at Christ-church Oxford is notable, and though not so light as a gothic architect would perhaps have formed it, does not disgrace the modern'. ${ }^{22}$ In Walpole's pro-Gothic eyes, it does not disgrace the modern because it attempted to embrace the medieval style, even if it failed ultimately to realise the Gothic's 'lightness'. Walpole may well not have possessed the visual knowledge necessary to articulate the irregularities of Tom Tower, but he could certainly differentiate between Wren's contribution and that of the original Tudor fabric, or between modern utilisations of the mode and medieval Gothic architecture in general.

Although unrealised, Wren's Warrant Design (1675) for St Paul's Cathedral also embraced Gothic forms. After the rejection of the unconventional Great Model (1763-4), Wren offered the cathedral's Chapter a far more traditional, medieval-structured building with a tall nave flanked by lower side aisles. ${ }^{23}$ What would be formed from pointed arches (vaulting and window openings) in a Gothic Cathedral were instead rendered in a Classical manner and replaced with round-headed variants, pilasters substituting the high vault's responds. Wren's conservative design, consequently, was essentially a Gothic cathedral completely rewritten in Classical form and ornament. Although this design was not executed, the realised fabric makes use of flying buttresses - that

2I Wren, 'Tom Tower', p. I7.

22 Horace Walpole, Anecdotes of Painting in England; with Some Account of the Principal Artists; and Notes on Other Arts; Collected by G. Vertue, and Now Digested from His MSS, 3rd edition, 4 vols (London: Printed for J. Dodsley, I782), vol. 3, pp. I67-8.

23 Oxford, All Souls College, II.I4. See Kerry Downes, Sir Christopher Wren: The Design of St Paul's Cathedral (London: Trefoil in association with Guildhall Library, 1988) and Anthony Geraghty, The Architectural Drawings of Sir Christopher Wren at All Souls College, Oxford: A Complete Catalogue (Aldershot: Ashgate, 2007), pp. 62-3. 
distinctive feature of the great Gothic churches - while keeping them hidden behind Classicised screen walls. Wren's most well-known Classical essay, is, consequently, indebted to medieval architectural forms and structures obfuscated by a Classical veneer. Despite its limited scale, Wren's Gothic output reveals that it was not inconceivable for a thoroughly Classical architect to embrace the Gothic, even if it was not considered a valuable and tasteful architectural style.

\section{Nicholas Hawksmoor}

Hawksmoor, Wren's pupil, worked in his mentor's Classical-Gothic hybrid style, and similarly completed medieval structures. His most significant work is a range of buildings forming the North Quadrangle (Fig.4.I) at All Souls College, Oxford (1708-30). Of the additions, the pair of towers in the quadrangle and the copula over the Radcliffe Square gate are the most significant. Together, they illustrate Hawksmoor's understanding of medieval architectural forms, but also his persistent use of these motifs within the Classical frameworks of proportion and ornament. His unexecuted I708-9 design for the college's High Street façade, replete with Gothic forms including crenellations, crocketed pinnacles, aedicular niches, buttresses, registers of trefoilcusped lancets and ogee-flip crestings, is entirely symmetrical and regimented by round-headed windows. ${ }^{24}$ An unexecuted proposal for the North Quadrangle's square-plan towers in perspective shows the buttresses terminating just above the main register's recessed window openings, and the level above is left plain, save for a trio of narrow early English-style lancet windows on each face, above which rises a two-story embattled and buttressed octagon on each tower. ${ }^{25}$ The towers, as executed, are more ornamentally ambitious and coherent, yet they retain this design's inconsistent application of buttresses and simplified, even plain, surface treatment. Perhaps the most incongruous piece of executed work from this programme is the entranceway from Radcliffe Square. The late-Gothic, Perpendicular-style onion dome akin to those on the buttresses of King's College, Cambridge, and Henry VII's Chapel, Westminster Abbey, is not finished with a suitably Gothic finial as seen in these Tudor examples, but with a Corinthian capital. A 1720 proposal for the Radcliffe Square façade and tower ${ }^{26}$ that, like the High Street façade, ${ }^{27}$ mixes round-headed windows among Gothic buttressing and pinnacles, does

24 Oxford, Worcester College, YD4, f. I3I. 26 Oxford, Worcester College, YD4, f. I27.
25 Oxford, Worcester College, YD4, f. 2.

27 Oxford, Worcester College, YD4, f. I3I. 


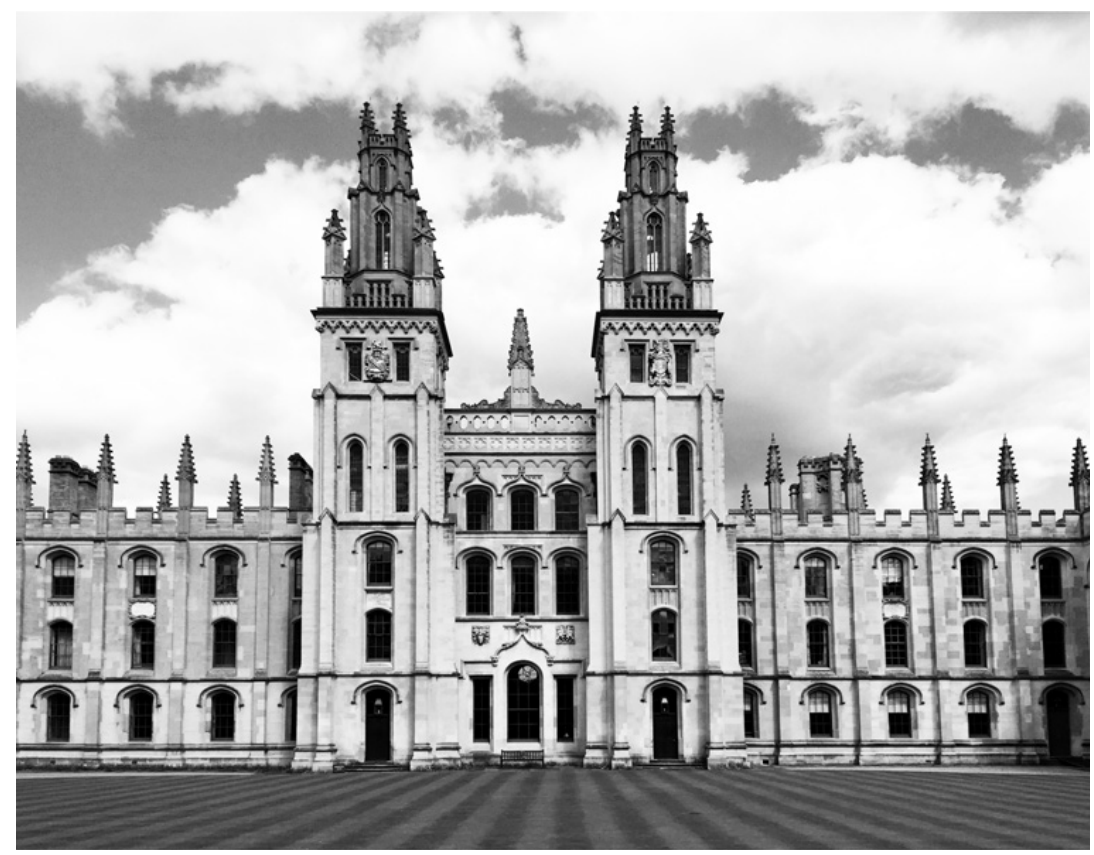

Fig.4.I: Nicholas Hawksmoor, North Quadrangle towers and east range, All Souls College, Oxford. Author's photograph.

not include this Corinthian capital; instead the dome is finished with a sphere, and even his Classically-styled screen and dome does not include this Corinthian capital, ${ }^{28}$ though it is perhaps hinted at in his perspective rendering of the North Quadrangle in red. ${ }^{29}$ This blatant mixture of Classical and Gothic forms within one apparently coherent scheme is not unusual in Hawksmoor's corpus, and a Corinthian capital can be found serving as a finial to the dome that he projected for Westminster Abbey's crossing tower. $^{30}$

Equally notable are Hawksmoor's additions to and completion of Westminster Abbey's western towers, which, much like Christ Church's tower, had been left unfinished in the medieval period. In $1712 \mathrm{Wren}$ wrote that 'the two West-towers [at the Abbey] were left incomplete, ... one much higher than the other, though still too low for Bells ... they ought certainly to be carried to an equal Height, one story above the Ridge of the Roof, still

28 Oxford, Worcester College, YD4, f. $5 . \quad 29$ Oxford, Worcester College, YD4, f. II. 30 London, Westminster Abbey Archives, Hawksmoor Drawings, no. 4. 
continuing in the Gothick Manner, in the Stone-work, and Tracery'. ${ }^{\text {I }}$ The northern tower was significantly lower, carried only up to just above the side aisle, whereas the southern tower was at the level of the high vault apex. Hawksmoor resolved the towers' design in I734. However, the additions above the top of the western window were not universally consistent with the medieval forms and ornament below. Hawksmoor's towers above an entablature, complete with Classical piercings, are divided into bold horizontal registers that, most noticeably over the clock and corresponding oculus, are framed by round pediments. The towers' louvred openings, while loosely mirroring tracery windows, are composed from simplified lancet shapes and reticulations that are noticeably lacking cusps in contradiction to the remainder of the structure below. Each opening's ogee-flip cresting is also finished uncomfortably with Corinthian-like capitals akin to that on the tower of All Souls' Radcliffe Square screen. Hawksmoor's mixture of Classical and Gothic elements in the western towers, and the resultant contradiction with the earlier medieval fabric, did not go unnoticed: as one commentator put it, it was 'not conformable and pursuant to the old'. ${ }^{32}$

Hawksmoor wrote about the Abbey's Gothic architecture in Classical terms: referring to the façade's gable, he claimed that 'as soon as the mason can get stone he will put on the Crockets (or Calceoli) at the West end on the pediment'. ${ }^{33}$ This mixture of Gothic and Classical forms could have expanded beyond the abbey's western towers to encompass the entire fabric. A c. I724 design reveals his plan to encase the structure's exterior in a form of simplified Gothic, with a Classical entablature suitably Gothicised and running above each of the three windows' levels. ${ }^{34}$ Another of Hawksmoor's proposals for the towers places a Corinthian capital at the top of each tower's proposed spire, with flying buttresses almost in the form of volute-scrolls and pedimented-tops to the upper panelling. ${ }^{35}$ Hawksmoor's additions to the Abbey, consequently, reflect his predilection for mixing Classical and Gothic architectural forms, albeit on a scale much more restrained than he had envisioned at one point.

Because of his work in Oxford and London, Hawksmoor, much like Wren, clearly perpetuated medieval forms, but in a manner quite different from the

3I Kerry Downes, Hawksmoor (London: A. Zwemmer, I959), p. 283.

32 Quoted in Vaughan Hart, Nicholas Hawksmoor: Rebuilding Ancient Wonders (New Haven and London: Yale University Press, 2002), p. 62.

33 Quoted in Hart, Nicholas Hawksmoor, p. 62.

34 London, Westminster City Archives, Gardner Box 53 ff. 6-7.

35 London, Westminster Abbey Archives, Hawksmoor Drawings, no. I7. 
local masons in the seventeenth and eighteenth centuries that Colvin framed as the exponents of Gothic Survival. Hawksmoor's Gothic works reinterpreted and re-composed medieval motifs and structural forms in a way that was never seen in the medieval period. Thus, although his Gothic works perpetuated the unbroken lineage of Gothic design in Britain, it was in a new, rejuvenated form that he responded to the prevailing and accepted architectural aesthetic of Classicism.

\section{Sir John Vanbrugh}

Vanbrugh, even more so than Wren, had a varied career. Well known today as a playwright (his The Relapse ran in London from I696, and a second comedy, The Provok'd Wife, opened in I697), he initially worked for William Matthews, a paternal cousin, in the London wine business, and then as a factor in the East India Company. His first architectural commission was a palatial and highly influential one: Castle Howard, Yorkshire, for Charles Howard (I669-I738), 3rd Earl of Carlisle, and fellow member of the Kit-Cat Club that Horace Walpole believed contained 'the Patriots that saved Britain' ${ }^{36}$ Like the bulk of Wren's and Hawksmoor's architecture, Castle Howard is Classical. A good number of Vanbrugh's country houses, on the other hand, make repeated concessions to the medieval. While this may not be articulated as consistently as it was by Walpole at Strawberry Hill - indeed Walpole's villa is an essay recording his and his designers' increasingly rigorous comprehension and command of medieval architectural motifs - his use of the Gothic deliberately courted association with the historic, the chivalric and the masculine. ${ }^{37}$ This is what Vanbrugh referred to as the 'castle air'. As its name suggests, the 'castle air' created the impression of a robust medievalist fortification conveyed through a select range of architectural forms, including crenellations, machicolations, arrow-slits and massy walls. Vanbrugh's proposals for Inveraray Castle, Argyll, make use of all of these motifs to create a new-old medievalist country house (Fig.4.2). ${ }^{38}$ The preparatory sketch of $c$. 1720 illustrates the importance of all of these motifs, together with massy round-towers; however, the

36 James Caulfield, Memoirs of the Celebrated Persons Composing the Kit-Cat Club: With a Prefatory Account of the Origin of the Association (London, I82I), title page.

37 Vaughan Hart, Sir John Vanbrugh: Storyteller in Stone (New Haven and London: Yale University Press, 2008), pp. 45-8I.

38 Victoria and Albert Museum, London, E.2I24:79-I992 and E.2124:I38-I992. 


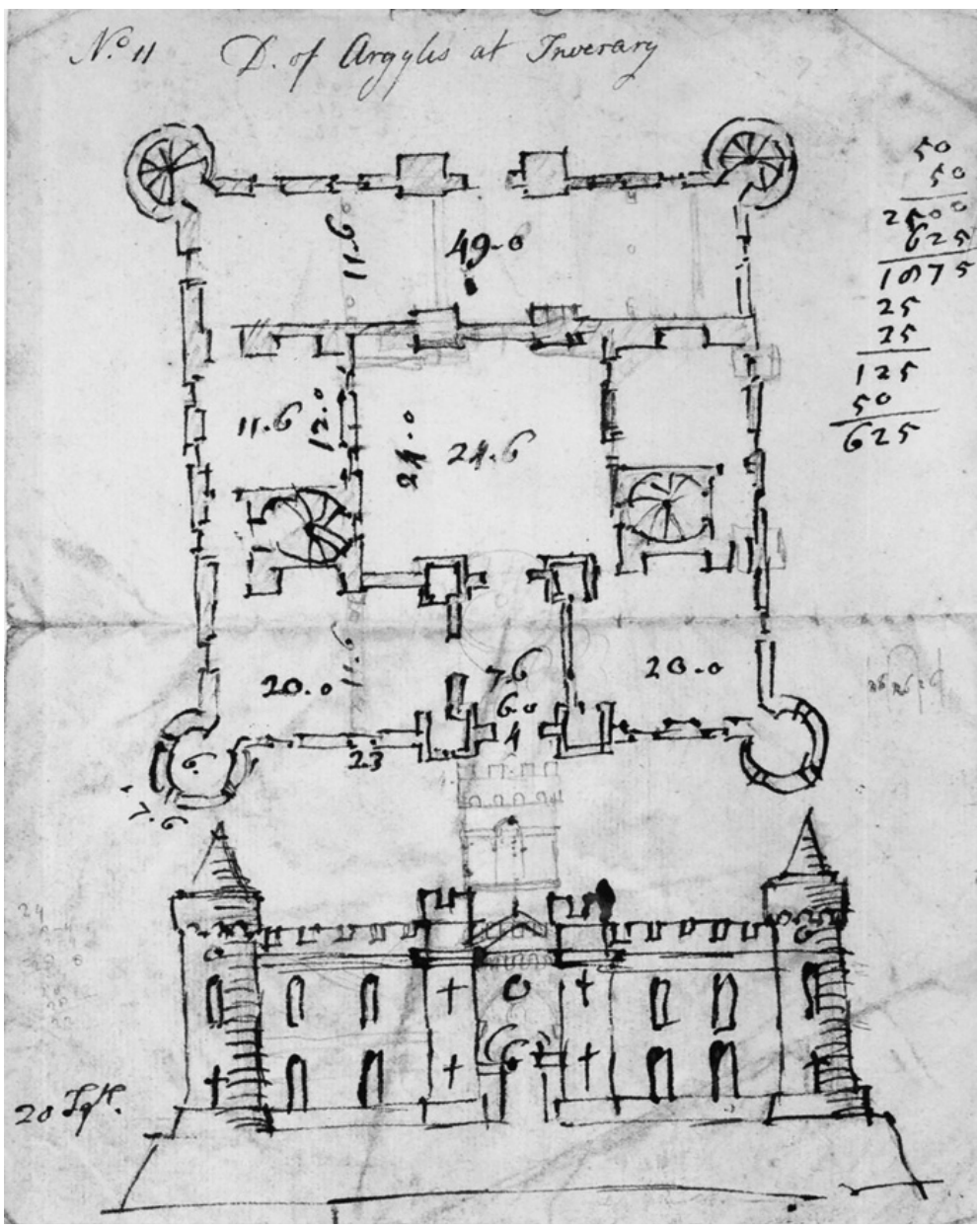

Fig.4.2: Sir John Vanbrugh, Sketch plan and elevation of Inveraray Castle, Argyll. c. 1720. E.2124:79-1992. (C) Victoria and Albert Museum, London.

large round-headed windows and symmetrical façade contradict this medievalist style. ${ }^{39}$ A presentation design for the house makes a rare concession in his oeuvre to the pointed arch by incorporating two Gothic relieving arches above the portal. ${ }^{40}$ 
At Kimbolton Castle, Cambridgeshire, Vanbrugh was employed by Charles Montagu (c. I662-1722), Ist Duke of Manchester, to repair the house following the collapse of the garden (south) façade. This fabric, in need of attention, played directly into Vanbrugh's predilection for creating castellated allusions. Writing to the Countess of Manchester in 1707, Vanbrugh indicates his interest in restoring the house and incorporating references to the medieval - the house, after all, was medieval at heart and the medievalising refurbishment would thus not be too inappropriate: 'As to the Outside, I thought 'twas absolutely best, to give it something of the Castle Air, tho' at the Same time to make it regular. And by this means too, all the Old Stone is Serviceable again; which to have had the new would have run to a very great Expense. ${ }^{41}$ Sensitive to the proposal's mixture of Gothic and Classical architectural components, Vanbrugh convincingly acknowledges his reinterpretation of medieval design and his deviation from orthodox Classical architecture: 'I hope your $\mathrm{L}^{\mathrm{d}}$ ship won't be discourage'd, if any Italians you may Shew it to, shou'd find fault 'tis not Roman, for to have built a Front with Pillasters, and what the Orders require cou'd never have been born with the Rest of the Castle'. ${ }^{42}$ The façade designs, orchestrated according to regular proportion and dominated by round-headed windows, are crowned with crenellations to convey the castle air. ${ }^{43}$ This repertoire is also found on a façade proposal for an unknown house, illustrating the repeated use of this aesthetic trope. ${ }^{44}$

In his $c$. 1718-23 proposal for Sir William Saunderson's House, Greenwich, the castle air is confined to the faux machicolations. ${ }^{45}$ This deployment contradicts directly the Venetian window inserted into the second story. A similar repertoire of ornament was applied to Vanbrugh's own house, Vanbrugh Castle, Greenwich, a massy brick structure dominated by a circular staircase. ${ }^{46}$ Vanbrugh, in the same manner as the architects considered already, advanced a style of Gothic architecture that was personal to his own interpretation. Vanbrugh's Gothic - the castle air - consequently offered a new and distinctly Georgian reinterpretation of the medieval that, like the Gothic of Wren and Hawksmoor, owed a considerable debt to the forms and principles of prevailing Classical design.

4I Bonamy Dobrée and Geoffrey Webb (eds), The Complete Works of Sir John Vanbrugh, Vol. 4 (London: Nonesuch Press, I928), p. I4.

42 Dobrée and Webb (eds), p. I4.

43 Victoria and Albert Museum, London, D.97-I89I; D.I09-I89I; D.II2-I89I.

44 Victoria and Albert Museum, London, E.2124:I49-I992.

45 Victoria and Albert Museum, London, E.2124:I29-I992.

46 Hart, Nicholas Hawksmoor, pp. 213-4I. 


\section{William Kent}

The same mixture of styles emerges in the work of William Kent, a painter, designer and architect who was 'discovered' by Richard Boyle (I694-I753), 3rd Earl of Burlington and 4th Earl of Cork, and referred to by Horace Walpole as 'a proper priest' to Burlington's 'Apollo of Arts' ${ }^{47}$ Kent's work is overwhelmingly Classical - unsurprisingly so, given his decade-long Italian sojourn but he can nevertheless be connected firmly to several significant examples of Gothic Revival design between $c$. 1729 and 174I. These range in scale from modest cartoons for book illustrations ${ }^{48}$ through to country house architecture and interiors, ${ }^{49}$ and perhaps even a Herefordshire church in 1748 (the year of his death) for a friend and correspondent of Walpole's, Dickie Bateman (c. 1705-74)..$^{50}$

A number of Kent's book illustrations, executed perhaps as early as 1729 for the 175I edition of Edmund Spenser's metrical romance The Faerie Queene (1590-6), demonstrate the breadth and complexity of his style. They confirm that he was interested in creating a Gothic effect without actually attempting to recreate the exact form, appearance and structure of medieval English architecture. As I have written elsewhere, his illustration of The Redcross Knight Introduced by Duessa to the House of Pride (Fig.4.3) sets a relatively convincing Gothic hall in the background, in front of which appears confused foreground architecture comprising what is effectively a Classical Ionic colonnade and gatehouse peppered with Gothic ogee arches, quatrefoils and trefoil-cusped arches. ${ }^{5 \mathrm{I}}$ His illustration of the Italianate castle in Arthegal

47 Horace Walpole, Anecdotes of Painting in England; with Some Account of the Principal Artists; and Notes on Other Arts; Collected by G. Vertue, and Now Digested from His MSS, 4 vols (Strawberry Hill: Printed by Thomas Farmer, I762-7I[i.e. I780]), vol 4, p. III. See Susan Weber (ed.), William Kent: Designing Georgian Britain (New Haven and London: Yale University Press, 20I3), pp. 27-I8I.

48 Nicholas Savage, 'Kent as Book Illustrator', in Weber (ed.), William Kent, pp. 4I2-47.

49 Julius Bryant, "From "Gusto" to "Kentissime": Kent's Designs for Country Houses, Villas, and Lodges', in Weber (ed.), William Kent, pp. I83-24I.

50 See Matthew M. Reeve, 'Dickie Bateman and the gothicization of Old Windsor: architecture and sexuality in the circle of Horace Walpole', Architectural History 56 (20I3): 97-I3I; Howard Colvin, 'Henry Flitcroft, William Kent and Shobdon Church, Herefordshire', in David Jones and Sam McKinstry (eds), Essays in Scots and English Architectural History: A Festschrift in Honour of John Frew (Donington: Shaun Tyas, 2009), pp. I-8; Peter N. Lindfield, Georgian Gothic: Medievalist Architecture, Furniture and Interiors, 1730-1840 (Woodbridge: Boydell and Brewer, 20I6), pp. 7I-8; and Roger White, 'William Kent and the Gothic Revival', in Susan Weber (ed.), William Kent, pp. 247-69 (p. 264).

5I London, Victoria and Albert Museum, E.876-1928. See Peter N. Lindfield, "Hung Round with the Helmets, Breast-Plates, and Swords of Our Ancestors": Allusions to Chivalry in Eighteenth-Century Gothicism?', in Barbara Gribling and Katie Stevenson 


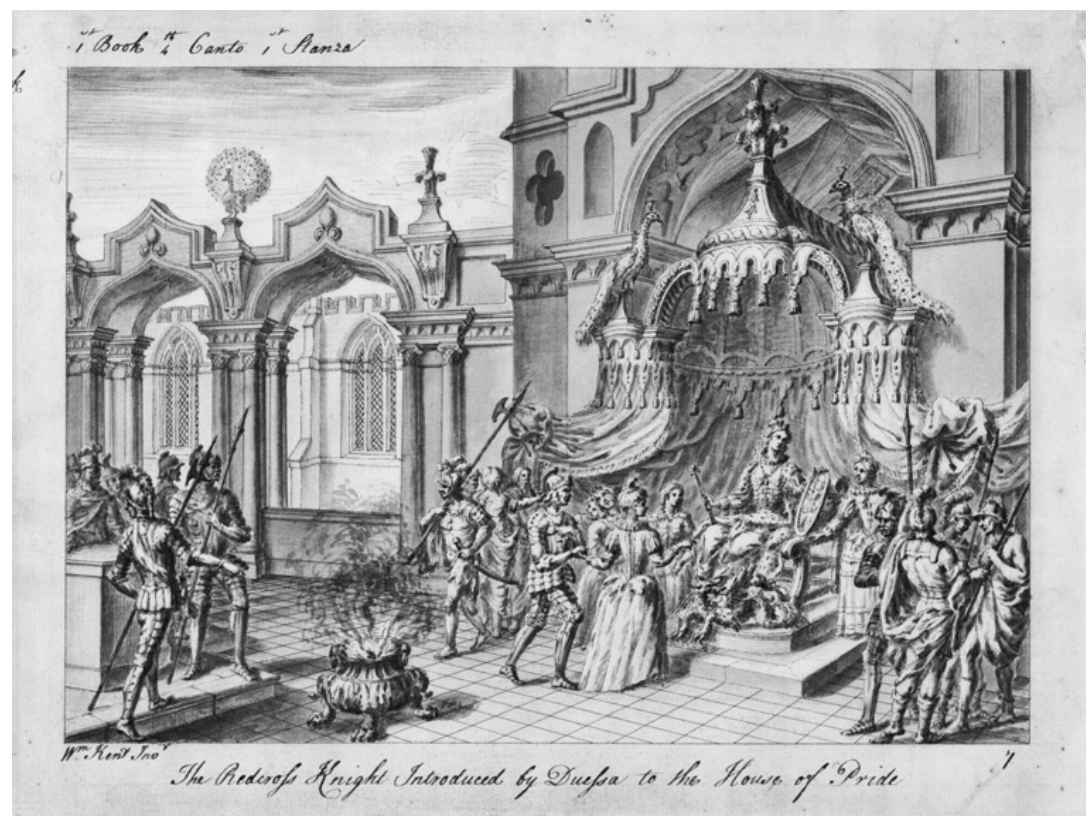

Fig.4.3: William Kent, Cartoon of The Redcross Knight Introduced by Duessa to the House of Pride. c. 1729-40. E.876-1928. (C) Victoria and Albert Museum, London.

Fights the Sarazin Pollente is made overtly Gothic by the overabundance of arrow-slits, and domestic rather than militaristic ogee and Tudor windows and doorways. ${ }^{52}$ Even when attempting to recreate extant architecture, such as Hampton Court Palace's interior and exterior, Kent exercised significant 'artistic license' in reconfiguring the historic Gothic architecture. His depiction of Henry VIII Receiving Montmorency, the French Ambassador, at Hampton Court replaces the rigidly Perpendicular tracery patterns of the Great Hall's west window with a far more Decorated - and typically Kentian - type of tracery found in numerous other examples of his Gothic work, in which a quatrefoil is 'punched' though a piece of masonry (plate tracery from the twelfth century) at the window's head, and the remainder of the window is made from circa fourteenth-century bar tracery. ${ }^{53}$ Kent also substituted the

(eds), Chivalry and the Vision of the Medieval Past (Woodbridge: Boydell and Brewer, 20I6), pp. 74-6.

52 London, Victoria and Albert Museum, E.892-I928.

53 London, British Museum, I927-7-2I-4. 
hammer beam roof in Hampton Court Palace's Great Hall with a type of pendant vaulting more akin to that found in the Palace's Chapel Royal.

Similar artistic liberties were taken with his rendering of Hampton Court Palace from the outside. Kent's capriccio landscape for Michael Drayton's 'Poly-Olbion' depicts Hampton Court Palace to the left of the scene, although he significantly enlarged the scale of the Palace's Great Hall, completely rewrote its main western window's tracery again, and apparently combined the Entrance and Clock towers into one, or omitted the Entrance façade and court entirely. ${ }^{54}$ This depiction is, at best, only a vague representation rather than an accurate depiction of the Palace. Kent's artistic liberty did not extend, on the other hand, to his rendition of Esher Place, a country house that he designed, to the right of this landscape. Kent designed and executed the house in the Gothic mode in $c$. I730-3 for Henry Pelham (1694-I754), a future prime minister, around the time that he partially remodelled the Clock Court tower at Hampton Court Palace. ${ }^{55}$ But unlike his modest remodelling of the Clock Court tower, Esher Place is his most significant, though now largely demolished, work in the style (Fig.4.4). Despite the scale and importance of the structure to his admittedly limited Gothic oeuvre, the exact genesis and nature of the commission is far from certain. A number of Kent's designs for the house's exterior and interior reveal important aspects not only of the house, but also of his Gothic 'style'..$^{56}$ One indicates that the house would have been a modest square-plan Palladian pile with pavilions on a knoll. ${ }^{57}$ Kent's drawing sets the Classically styled house in front of a gatehouse serving as a folly; this gatehouse was all that remained of the medieval house erected $c$. I480 by William Waynflete (I398-I486), Bishop of Winchester. For some reason, Kent's designs shifted to embrace the Gothic, and instead of employing Waynflete's tower as a folly, the medieval fragment became the centre of the new house. ${ }^{58}$ His proposal for Esher, exhibiting Palladian simplicity, proportion and geometry, is replete with medieval-derived motifs applied to the façade to articulate a Gothic appearance with the gatehouse at its centre. A design by Kent for Esher's octagonal room demonstrates how he Gothicised a standard pedimented (Classical) door-surround as found, for example, in his interiors at Houghton Hall, Norfolk, by replacing the

54 London, British Museum, 1927, 0721.5

55 Juliet Allan, 'New light on William Kent at Hampton Court Palace', Architectural History 27 (1984): 50-8.

56 John Harris, 'A William Kent Discovery: Designs for Esher Place, Surrey', Country Life (I4 May 1959): I076-8 and Harris, 'Esher Place, Surrey', Country Life (2 April 1987): 94-7.

57 London, Victoria and Albert Museum, E.360-1986.

58 London, Victoria and Albert Museum, E.36I-I986. 


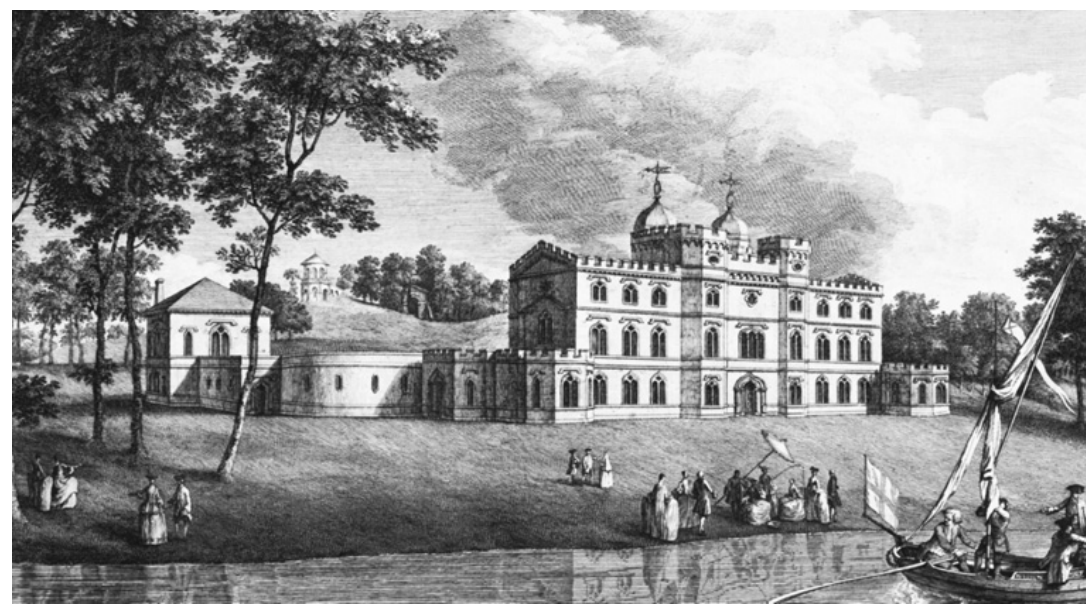

Fig.4.4: After Luke Sullivan, Detail of A View of Esher in Surrey, the Seat of the Rt. Hon. Henry Pelham Esq. 1759. Bi978.43.I075. Yale Center for British Art, Paul Mellon Collection.

entablature with an ogee arch, while the window exhibits his anachronistic combination of plate and bar tracery as found in his drawing of Henry VIII Receiving Montmorency. ${ }^{59}$ An engraved record of one chimneypiece by Kent for Esher was included by John Vardy's Some Designs of Mr. Inigo Jones and Mr. Wm. Kent (I744), which demonstrates perhaps Kent's most limited additions of Gothic forms in the entablature (ogee-quatrefoils) to an otherwise exclusively Classical chimneypiece to give it a medievalist tincture.

Kent's two screens - for The Court of King's Bench in Westminster Hall, I739, and Gloucester Cathedral, I74I (Fig.4.5) - are similarly Classical-Gothic hybrids. ${ }^{60}$ Certain aspects of these two screens are particularly significant for the way in which overtly Classical forms, such as entablatures, columns and pilasters, are not only made fit for Gothic designs, but also modified subtly to become Gothic themselves. On both screens, the entablatures are staffed by a repeated gallery of blind cusped arcades, and the blind pedimented doorway on the upper register of the Gloucester screen is made 'medieval' by converting the rectilinear pediments into ogee arches. This, as seen in the next section on Batty Langley, had a significant impact upon eighteenth-century Gothic Revivalist architecture. Another of Kent's commissions, his work at

59 London, Victoria and Albert Museum, E.368-I986.

60 William Kent and Inigo Jones, Some Designs of $\mathrm{Mr}$. Inigo Jones and $\mathrm{Mr}$. Wm. Kent (London, I744), pls. 48-9. 


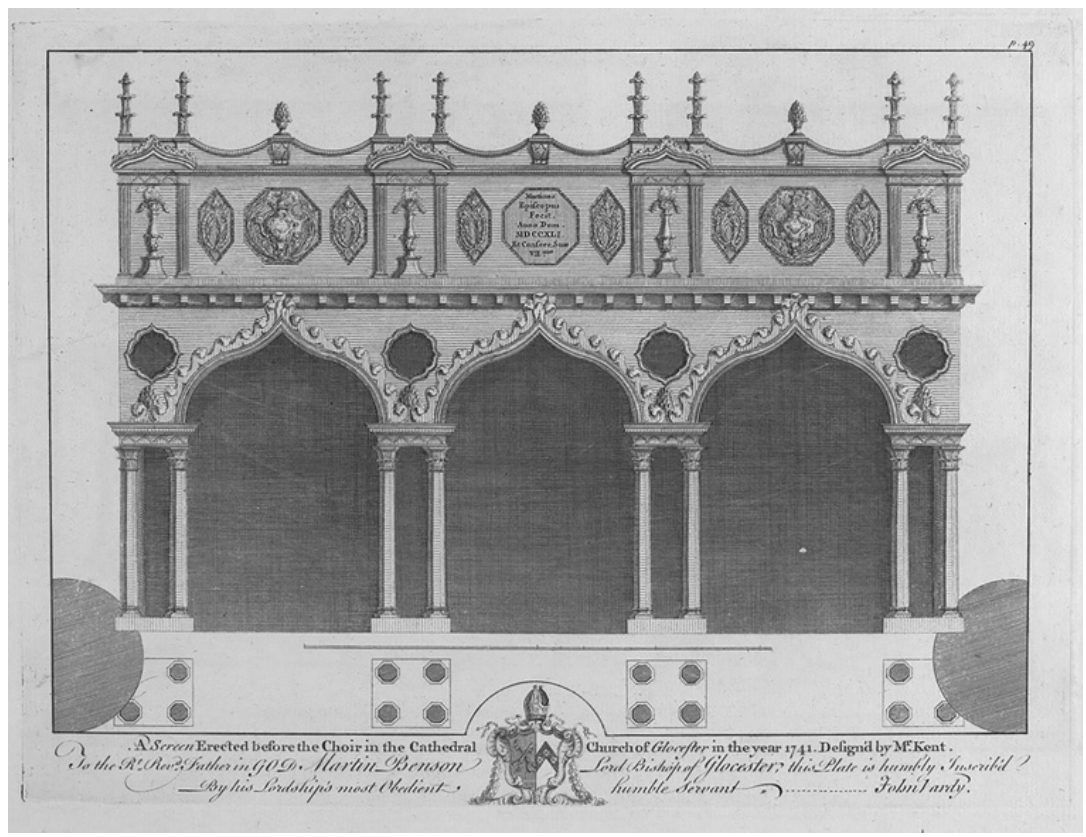

Fig.4.5: William Kent, A Screen Erected before the Choir in the Cathedral Church of Gloucester, I74I. Plate 49 from John Vardy, Some Designs of Mr. Inigo Jones and Mr. Wm. Kent (1744). Folio A N 63. Yale Center for British Art, Paul Mellon Collection.

York Minster in I74I, offers a second, distinct strand of Gothic that also had a significant impact upon Georgian Gothic design, including a cabinet for Henrietta Louisa (I698-176I), Countess of Pomfret, and the furniture for Shobdon Church, Herefordshire. ${ }^{61}$ Whereas the majority of Kent's Gothic designs were largely Classical in form and structure, his contributions to the Minster were, on the other hand, overwhelmingly Gothic: the pulpit and stalls, which, in comparison with his additions to Westminster Hall and Gloucester Cathedral, were sympathetic to their location in the Minster's Gothic Choir.

Despite offering only a limited range of designs for houses and furniture, Kent had a significant impact upon Gothic design until the 1760 s, in part due to Vardy's Some Designs of i744. Walpole certainly did not

6I Terry Friedman, 'The transformation of York Minster, I726-42', Architectural History 38 (1995): 69-90 (pp. 8I-3). See Peter N. Lindfield, 'The Countess of Pomfret's gothic revival furniture', The Georgian Group Journal xxii (2014): 77-94 and Lindfield, Georgian Gothic, pp. 7I-7. 
approve of Kent's Gothic, reflecting in September 1753 that 'Kent designed the screen [at Gloucester Cathedral]; but he knew no more there than he did anywhere else how to enter into the true Gothic taste. $^{.62}$ His disapproval of Kent's Gothic, especially at Gloucester Cathedral, did not stop the architect William Robinson reproducing, quite closely, Kent's Esher chimneypiece as illustrated by Vardy in his Some Designs for the Breakfast Room at Strawberry Hill. Walpole and his designers moved away from Kent's style of Gothic in the r750s, though, reviewing the house on 5 June 1788 in a letter to Thomas Barrett of Lee Priory, Kent, Walpole claimed that 'neither Mr. Bentley nor my workmen has studied the science [of Gothic], and [that ...] My house therefore is but a sketch by beginners'. ${ }^{63}$ Kent's Gothic certainly falls short of Walpole's later 'scientific' understanding and application of medieval forms, but Kent was nonetheless an important designer for promoting a distinct type of Gothic that was suitable across many different contexts, both domestic or ecclesiastical, and for the remodelling of medieval architecture to create a new country house.

\section{Batty Langley}

Of all the early Georgian Gothic designers, Langley is, without doubt, the most well known but also the most notorious. This arises partly from Walpole's assessment of the Twickenham-based amateur architect and garden designer. His best-known contribution to eighteenth-century design is his pattern-book, Ancient Architecture: Restored and Improved (I74I-2), which he reissued in 1747 as Gothic Architecture, Improved by Rules and Proportions. The book's designs advocate, principally through five Gothic 'Orders', a style of Gothic that is articulated through motifs frequently applied to Classical frameworks. Rather than proposing designs based upon the forms and structures of medieval architecture, Langley promoted a style founded upon Classical architecture: its Orders, framework of columns, entablatures, colonnades and Vitruvian proportions. Langley's re-presentation and theorisation of medieval architecture was designed to achieve a personal goal, namely to elevate Gothic architecture from a degraded and insular style lacking the intellectual

62 W. S. Lewis (ed.), The Yale Edition of Horace Walpole's Correspondence, 48 vols (New Haven and London: Yale University Press, 1937-83), vol. 35, p. I54.

63 Horace Walpole, The Works of Horatio Walpole, Earl of Orford, 5 vols (London: Printed for G. G. and J. Robinson and J. Edwards, I798), vol. 5, pp. 668-9. 
rigour and prestige of Classicism. ${ }^{64}$ This is evident in Wren's assessment of Classical and Gothic architecture, but these opinions can also be found in the work of other writers such as John Evelyn. ${ }^{65}$ Walpole also articulated the intellectual and emotional differences separating these two styles on a number of occasions, perhaps the most concise being in the fourth volume of his Anecdotes of Painting (1762):

one must have taste to be sensible of the beauties of Grecian architecture; one only wants passions to feel Gothic. In St. Peter's one is convinced that it was built by great princes. In Westminster abbey, one thinks not of the builder; the religion of the place makes the first impression - and though stripped of its altars and shrines, it is nearer converting one to popery than all the regular pageantry of Roman domes. Gothic churches infuse superstition; Grecian, admiration. $^{66}$

This critical distinction between the Classical and the Gothic styles was widely held at the time, and structured much eighteenth-century architectural thought, aesthetics and practice.

Attempting to overturn received opinion, Langley proposed in the dedication of Ancient Architecture to Charles, Duke of Richmond, that it is a 'Specimen (or Attempt) to restore the Rules of the ANCIENT SAxON Architecture, (vulgarly, but mistakenly called Gothic) which have been lost to the Public for upwards of seven hundred Years past' ${ }^{67}$ In the patternbook's second dedication, here to the Dean and Chapter of Westminster Abbey, he similarly underscored the originality of his publication, spuriously claiming that it sought to recover those aspects of medieval architecture that made it intellectually respectable:

by strict Researches, I have discovered many of the Rules by which its principal Parts are proportioned and adorned, whose Result commands the Admiration and Attention of all Beholders: And as, by great Variety of Examples, I have Illustrated their Uses, in the Formation, Ornamenting of

64 Eileen Harris, 'Batty Langley: a tutor to freemasons (I696-I75I)', Burlington Magazine II9:890 (I977): 327-35.

65 John Evelyn, An Account of Architects and Architecture, Together, with an Historical, Etymological Explanation of Certain Terms, Particularly Affected by Architects (London, I706), pp. 9-Io. See Peter N. Lindfield, "Serious gothic" and "doing the ancient buildings": Batty Langley's Ancient Architecture and Principal Geometric Elevations, Architectural History 57 (20I4): I4I-73.

66 Horace Walpole, Anecdotes of Painting in England, vol. 4, pp. II4-I5.

67 Batty Langley and T. Langley, Ancient Architecture: Restored, and Improved, by a Great Variety of Grand and Useful Designs, Entirely New in the Gothick Mode for the Ornamenting of Buildings and Gardens Exceeding Every Thing That's Extant (London, I74I-2), Dedication I. 
private Buildings, in the same Mode, which never was done, or attempted before; and as such may justly be esteemed an Improvement in the Noble Art of Building. ${ }^{68}$

Langley's pattern-book was criticised, not least by Horace Walpole. In a letter from 5 July 1755 to Richard Bentley, one of the designers of Strawberry Hill, Walpole writes of Latimers, Chesham, Buckinghamshire, that 'the house has undergone the Batty Langley-discipline: half the ornaments are of his bastard Gothic ... I want to write over the doors of most modern edifices, Repaired and beautified, Langley and Hallet churchwardens'. 69 In Anecdotes of Painting, Langley's Gothic is equally derided: he 'endeavoured to adapt Gothic architecture to Roman measures', Walpole writes, 'as Sir Philip Sidney attempted to regulate English verse by Roman feet. Langley went farther, and (for he never copied Gothic) invented five orders for that style' ${ }^{\circ}$ Later, in I872, Charles Locke Eastlake pronounced that,

Gothic architecture has had its vicissitudes in this country. There was a time when its principles were universally recognised; there was a time when they were neglected or forgotten. But in the days of its lowest degradation, it may be questioned whether it would not have been better that the cause should have remained unexposed than have been sustained by such a champion as Batty Langley. ${ }^{7 \mathrm{I}}$

Despite this criticism, Langley's Gothic was, in fact, rather influential, not least because he produced the first Georgian pattern-book to advance designs for architecture relevant to the eighteenth century. His plates included proposals for garden buildings, including pavilions and umbrellos, windows, chimneypieces and fireplaces.

While there is no evidence to indicate that Langley ever executed any of his designs, ${ }^{72}$ his plates had significant impact upon mid-Georgian Gothic, especially on pieces executed by local builders. William Porden, writing about a chimneypiece design for Eaton Hall, Chester, on 28 December I804, indicates the wide popularity and uptake of Langley's proposals: 'I have only to object that it has been executed in every Gothicised Cottage

68 Langley and Langley, Dedication 2.

69 Walpole, in Lewis, Horace Walpole's Correspondence, vol. 35, p. 233.

70 Walpole, Anecdotes of Painting, vol. 4, pp. Io6-7.

7I Charles Locke Eastlake, A History of the Gothic Revival, p. 54.

72 Timothy Mowl and Brian Earnshaw, An Insular Rococo: Architecture, Politics and Society in Ireland and England, 1710-1770 (London: Reaktion, 1999), p. 99. See also Roger White, 'The Influence of Batty Langley', in J. Mordaunt Crooke (ed.), A Gothick Symposium at the Victoria and Albert Museum (London: Victoria and Albert Museum, 1984), no. pag. 
these 50 years and was originally designed by Batty Langley. In short, it was only what was called a modern Chimney piece before the present French fashion became prevalent with the usual gothic ornament instead of the Grecian patera. ${ }^{73}$ Indeed, a chimneypiece added to the Family Pew at Shobdon Church, Herefordshire, c. 1755, exactly reproduces Plate XLIII from Langley's Ancient Architecture (174I-2). The Gothic Temple at Bramham Park, Yorkshire (I750), duplicates Plate LVII in Ancient Architecture, and the umbrello at Great Saxon Hall, Suffolk (c. I80I-I5), reflects the structure and many of the motifs found on Plates XXXI and LII of the same volume. ${ }^{74}$ Although Porden's assessment of Langlean Gothic is hyperbolic, the designs' influence cannot be understated. Langley created a formal and fully illustrated repertoire of Gothic ornament that had practical application: combined with one another, applied to architecturally unrelated surfaces and structures, and in whatever way that the designer wished. With Langley, Gothic Orders supporting an entablature, modelled directly upon a Classical colonnade, were, for the first time, a possibility.

Part of Langley's apparently unbridled influence stems from the fact that his designs were copied, imitated and paraphrased in the r750s. Each of William Pain's editions of The Builder's Companion and Workman's General Assistant (1758, 1765, I769), for instance, offered a version of Langley's five Gothic Orders and his other designs. ${ }^{75}$ Pain's Gothic Orders follow roughly those developed by Langley, although their sequence is re-arranged as follows: I, 3, 5, 2, 4. Pain also offered some designs in Langley's ClassicalGothic style, but of his own inventions. Plate 80, Four Gothick Frontispieces for outside Work, is a synthesis of Gothic Frontispieces from Ancient Architecture, but the shafts rise to support an entablature, upon which sit crenellations, a pediment or a Chinese Pagoda. Indeed, all four designs on Plate 80 feature square- headed doors, upon which token tracery details are added. Gothick Frontispieces for the Inside of Rooms, Plate 82, illustrates the flexibility of Gothic's appearance: the only parallel between the designs and medieval architecture is the arched decoration cut into some of the moulding patterns and panels either side of the jamb mouldings. Langley's style of ClassicalGothic architecture was, consequently, promoted by other designers and

73 Chester, Eaton Hall Archive, 9/278 28 December 1804, fol. Ir.

74 See Gwyn Headley, Follies, Grottoes \& Garden Buildings (London: Aurum, 1999), pp. 550-I.

75 Alistair John Rowan, 'Batty Langley's Gothic', in Giles Robertson and George Henderson (eds), Studies in Memory of David Talbot Rice (Edinburgh: Edinburgh University Press, I975), pp. I97-2I5 (p. 208). 
pattern-book authors keen to offer designs according to mid-eighteenthcentury fashion. A letter in The World from 1753 highlights Gothic's popularity at the time particularly well:

FROM a thousand instances of our imitative inclinations I shall select one or two, which have been, and still are notorious and general. A few years ago everything was Gothic; our houses, our beds, our book-cases, and our couches, were all copied from some parts or other of our old cathedrals. The Grecian architecture ... which was taught by nature and polished by the graces, was totally neglected. ${ }^{76}$

Numerous pattern-books supplied this fascination with the Gothic, though because Langley's came first, its place in the Gothic Revival has surpassed that of, for example, the prolific and influential work of William and John Halfpenny in their 1752 publications, Rural Architecture in the Gothick Taste and Chinese and Gothic Architecture Properly Ornamented.

\section{Coda}

Important though it was, Walpole's Strawberry Hill cannot be seen as the only or the most prominent example of 'new', or 'modern' Gothic architecture in eighteenth-century Britain. As this essay has shown, numerous examples were imagined, designed and realised by such figures as Wren, Hawksmoor, Vanbrugh, Kent and Langley, albeit often in hybrid, ClassicalGothic forms. While it is clear that Strawberry Hill witnessed and attested to an evolution in the Gothic style, particularly in Walpole's later turn towards archaeological and antiquarian precision, it cannot be taken to represent the genesis of the Gothic Revival of the eighteenth century in its entirety.

76 H. S. [William Whitehead], 'Number I2. Thursday 22 March I753', The World, pp. 67-72 (p. 68). 